\title{
PERLINDUNGAN HUKUM TERHADAP ANAK DI BAWAH UMUR KORBAN PERSETUBUHAN BERDASARKAN UNDANG-UNDANG NOMOR 35 TAHUN 2014 ATAS PERUBAHAN UNDANG-UNDANG NOMOR 23 TAHUN 2002 TENTANG PERLINDUNGAN ANAK
}

\author{
Burhayan \\ burhayan@unitaspalembang.ac.id \\ Fakultas Hukum Universitas Tamansiswa Palembang
}

\begin{abstract}
Perlindungan hukum terhadap anak merupakan upaya perlindungan berbagai kebebasan hak asasi anak (fundamental right and freedom of children) serta berbagai kepentingan yang berhubungan dengan kesejateraan anak. Perlindungan hukum bagi anak mencakup lingkup yang luas. Dalam perspektif kenegaraan, negara melindungi warga negaranya termasuk didalamnya terhadap anak dapat ditempatkan dalam pembukaan undang-undang Dasar 1945 yang tercermin pada alinea ke-IV, di dalam penjabaran BAB XA tentang Hak Asasi Manusia, khususnya untuk perlindungan terhadap anak. UUD 1945 jelas menyatakan bahwa negara memberikan perlindungan kepada fakir miskin dan anak-anak terlantar. Masalah kemiskinan semakin menjadi penyakit yang terus menerus muncul dinegara ini, termasuk berbagai kejahatan yang terjadi menimpa anak-anak dinegara ini, termasuk bebagai kejahatan yang terjadi menimpa anak-anak di negara ini yang faktor utamanya disebabkan oleh kemiskinan. Faktor kemiskinan ini mempunyai kontribusi besar dalam tindakan penelantaran anak yang dilakukan oleh orang tua kandung. Kemudian juga perlindungan spesifik hak anak sebagian dari hak Asasi manusia, masud dalam Pasal 28 B ayat (2) bahwa setiap anak berhak atas kelangsungan hidup, tumbuh dan berkembang, serta memperoleh perlindungan darim kekerasan dan diskrimnasi. Perlindungan Anak berdasarkan Pasal 1 ayat (2) Undang-undang Republik Indonesia Nomor 35 Tahun 2014 tentang perubahan atas undang-undang Nomor 23 Tahun 2002 tentang perlindungan anak menyatakan bahwa : Perlindimgan anak adalah kegiatan untuk menjamin dan melindungi anak dan hak-haknya agar dapat hidup, tumbuh, kembang dan berpartisipasi, secara optimal sesuai harkat dan martabat perlindungan dari kekerasan dan diskriminasi. Anak sebagai korban kesusilaan tentunya mengalami penderitaan, baik secara maupun psikis. Negara sbagai penjamin kehidupan bermasyarakat bermasud memberikan perlindungan secara khusus kepada anak agar terhindar dari upaya ekspoitasi oleh pihak-pihak tertentu. Salah satu instrumen yang digunakan dalam perlundungan anak adalah hukum perlindungan hukum bagi anak dapat diartikan sebagai upaya yang berhubungan dengan kesejateraan anak.
\end{abstract}

Kata Kunci: Perlindungan Anak

Abstract: Legal protection for children is an effort to protect various freedoms of children's rights (fundamental rights and freedom of children) as well as various interests related to children's welfare. Legal protection for children covers a wide scope. In the perspective of the state, the state protects its citizens, including children, can be placed in the preamble to the 1945 Constitution which is reflected in the fourth paragraph, in the elaboration of Chapter XA on Human Rights, especially for the protection of children. The 1945 Constitution clearly states that the state provides protection to the poor and neglected children. The problem of poverty is increasingly becoming a disease that continues to emerge in this country, including various crimes that happen to children in this country, including various crimes that happen to children in this country whose main factor is caused by poverty. This poverty factor has a major contribution in the neglect of children by biological parents. Then also the specific protection of children's rights as part of human rights, as stated in Article 28 B paragraph (2) that every child has the right to survive, grow and develop, and obtain protection from violence and discrimination. Child Protection based on Article 1 paragraph (2) of the Law of the Republic of Indonesia Number 35 of 2014 concerning amendments to Law Number 23 of 2002 concerning child protection states that: Child 


\section{Jurnal Tripantang}

Fakultas Hukum Universitas Tamansiswa Palembang

protection is an activity to guarantee and protect children and their rights so that they can live, grow, develop and participate optimally according to the dignity of protection from violence and discrimination. Children as victims of decency certainly experience suffering, both physically and psychologically. The state as a guarantor of social life aims to provide special protection to children in order to avoid exploitation by certain parties. One of the instruments used in child protection is the law of legal protection for children, which can be interpreted as an effort related to the welfare of children.

Keywords: Child Protection

\section{LATAR BELAKANG}

Anak sebagai mahluk Tuhan Yang Maha Esa dan mahluk, sosial, sejak dalam kandungan sampai melahirkan mempunyai hak atas hidup dan merdeka serta mendapat perlindungan baik dari orang tua, keluarga, masyarakat, bangsa dan negara. Oleh karena itu tidak ada setiap manusia atau pihak lain yang boleh merampas hak atas hidup dan merdeka tersebut. Bila anak itu masih dalam kandungan orang tua dan orang tua tersebut selalu berusaha untuk mengugurkan anaknya dalam kandungannya, maka orang tua tersebakan diproses hukum untuk mempertanggungjawabkan perbuatan yang melanggar hukum tersebut. ${ }^{1}$

Karena hak asasi anak tersebut merupakan bagian dari hak asasizi manusia yang mendapat jaminan dan perlindungan hukum baik hukum internasional maupun hukum nasional. Secara universal dilindungi dalam universal Declaration of human right (UDHR) dan internasional on Civil and Political Right (ICPR). Bahkan hak azaanak harus diperlukan berbeda dengan orang dewasa yang ditur secara khusus dalam konvensi-konvensi Internasional Khusus.

Anak berhak atas perlindungan-perlindungan lingkungan hidup yang dapat membahayakan atau menghambat pertumbuhan dan perkembangan dengan wajar. kedua ayat tersebut memberikan dasar dasar pemikiran bahwa perlindungan anak

${ }^{1}$ H.R. Abdussalam\& Adri Desasfuryanto, Hukum Perlindungan Anak, PTIK, Jakarta, 2014, hlm. 1 
bermaksud untuk mengupayakan pelaku yang benar dan adil, untuk mencapai kesejahteraan anak. $^{2}$

Gagasan mengenai hak anak berawal dari kenyataan bahwa anak berbeda dengan orang dewasa baik secara fisik, mental, maupun kondisi sosialnya. Oleh karenanya, seseorang wajib diberi perlindungan mulai ia didalam kandungan, seseorang anak, dilahirkan tumbuh dan berkembang untuk mendapatkan hak asasi manusianya secara utuh. Perlindungan hukum ini penting karena hukum memang segaja diciptakan sebagai tatanan yang difungsikan untuk melahirkan suatu ketertiban. $^{3}$

Dalam undang-undang No. 39 tahun 1999 tentang hak asasi manusia, menyebutkan setiap anak berhak atas perlindungan oleh orang tua, keluarga, masyarakat dan negara Pasal 52 ayat (1). ${ }^{4}$.

Adapun yang dimaksud dengan Hak Asasi Manusia dalam Pasal 1 UU No.39 Tahun 1999 Tentang HAM adalah: seperangkat hak yang melekat pada hakikat dan keberadaan manusia sebagai mekhluk Tuhan Yang Masa Esa dan merupakan anugerah-Nya yang wajib dihormati, dijunjung tinggi dan dilindungi oleh negara, hukum, Pemerintah, dan setiap orang demi kehormatan serta perlindungan harkat dan martabat manusia."

Untuk mendapatkan hak asasi manusianya secara utuh, anak perlu dilindungi secara hukum oleh lingkungan dimana ia berada mulai dari orang tua, keluarga, masyakarat, pemerintah daerah, pemerintah pusat, bahkan dunia internasional.

2 Nashriana, Perlindungan Hukum Pidana Bagi Anak Di Indonesia, Rajawali Press, Jakarta, 2011, hlm. 2

3 Satjipto Rahardjo, Biarkan Hukum Mengalir, Catatan Kritis Tentang Pergulatan manusia dan hukum, Kompas, Jakarta, 2008, hlm. 8

${ }^{4}$ Ibib, hlm. 27 


\section{Jurnal Tripantang}

Fakultas Hukum Universitas Tamansiswa Palembang

Setiap anak pada saat ia dilahirkan adalah termasuk subjek hukum yakni sebagai pribadi kodrati dimana ia dilahirkan dalam keadaan merdeka, tidak boleh disiksa atau bahkan dilenyapkan. Anak-anak bahkan sejak ia didalam kandungan mempunyai hak untuk hidup, dipelihara, dan dilindungi bagaimanapun kondisi fisik dan mental anak tersebut. Upaya pemenuhan hak anak dapat dilakukan terutama oleh orang tua dan keluarga, masyarakat, maupun bangsa dan negara. Hal itu disebabkan anak merupakan individu yang belum matang baik secara fisik, mental, maupun sosial sehingga bergantung pada orang dewasa. Kondisi anak yang rentan seperti itulah seringkali beresiko terhadap kegiatan yang mengandung unsur eksploitasi maupun kekerasan.

Di dalam UU Nomor 39 Tahun 1999 tentang hak asasi manusia dirumuskan 15 Pasal yang khusus merumuskan hak-hak anak, karena pembentuk UU menyadari bahwa anak merupakan kelompok yang rentang terhadap perlanggaran HAM. Lebih lanjut pengaturan hak-hak anak di Indonesia saat ini, juga diatur secara khusus dalam undang-undang Nomor 35 tahun 20014 atas perubahan UU No. 23 Tahun 2002 Tentang perlindungan Anak, dan keputusan pressiden No. 36 Tahun 1990 tentang pengesahan konvensi hak-hak anak. Dalam Pasal 1 butir 12 UU Nomor 35 tahun 2014 tentang perlindungan anak disebutkan bahwa hak adalah bagian dari hak asasi manusia yang wajib dijamin, dilidungi, dan dipenuhi oleh orang tua, keluarga, masyarakat, pemerintah dan negara. UU No. 35 tahun 2014 tentang perlindungan anak sendiri merupakan bentuk konkretisasi dari pelaksanaan konvensi hak-hak anak yang telah diratifikasi oleh Indonesia.

Menurut Pasal 1 Konvensi Hak Anak yang disetujui oleh Majelis Umum Perserikatan Bangsa-Bangsa pada tanggal 20 November 1989, UU No. 26/2000 Tentang Pengadilan HAM dan UU No.1 Tahun 2000 Tentang Pengesahan Konvensi ILO No. 182, anak didefinisikan sebagai: "setiap manusia yang berusia delapan belas tahun kecuali undang-undang yang berlaku terhadap anak, kedewasaan telah dicapai lebih cepat." Sementara menurut Pasal 1 Ayat 1 UU Nomor 35 Tahun 2014 
tentang perubahan Atas Undang-undang No.23 Tahun 2002 Tentang Perlindungan Anak anak disebut sebagai: "seseorang yang belum berusia 18 delapan belas tahun, termasuk anak yang masih dalam kandungan."

Setiap peraturan perundang-undangan telah mengatur secara tersendiri menegenai keteria anak yang tentunya sangat berpengaruh pada kedudukan hukum anak sebagai subjek hukum. Dalam hukum Indonesia terdapat pluralisme mengenai batas usia, hal ini yang menyebabkan tiap peraturan perundang-undangan mengatur secara tersendiri mengenai keteria anak. ${ }^{5}$

Contoh kasus seorang pria inisial BGW (38) ditangkap Warga setelah melakukan pencabulan terhadap anak tirinya yang masih berusia 12 tahun BGW ditangkap ditempat tinggalnya jalan musyawarah, kampong sawah, ciputat tangerang selatan. Ketua Rt setempat ahmad Sofyan menjelaskan peristiwa penangkapan BGW berawal dari adanya laporan tante atau bibi korban mengenai korban mengenai dugaan pencabulan itu. ${ }^{6}$

Bagaimana Perlindungan hukum terhadap anak di bawah umur korban persetubuhan ditinjau dari Undang-Undang Nomor 35 Tahun 2014 atas Perubahan Undang-undang Nomor 23 tahun 2002 tentang perlindungan anak ?

Pengertian korban seperti yang tercantum dalam Pasal 1 angka 2 undangundang Republik Indonesia Nomor 13 Tahun 2006 tentang perlindungan saksi dan korban menyatakan bahwa korban adalah seseorang yang mengalami penderitaan fisik, mental, atau kerugian ekonomi yang diakibatkan oleh suatu tindak pidana. ${ }^{7}$ Selanjutnya pandangan hukum Positif terhadap perlindungan anak korban kejahatan seksual dilihat dari undang-undang Republik Indonesia Nomor 13 tahun

${ }^{5}$ Darwin Prints, Hukum Anak Indonesia, (Citra Bakti, Bandung, 2002, hlm. 2

${ }^{6}$ https://ww.kompas.com tag diakses tanggal 14-4-2021 jam 14.00 Wib

7 Titon Slamet Kurnia, Reparasi terhadap korban Pelanggaran HAM di Indonesia, Bandung, 2005, Aditya Bakti, hlm. 6-7 


\section{Jurnal Tripantang}

Fakultas Hukum Universitas Tamansiswa Palembang

2006 Tentang perlindungan saksi dan korban. Hak asasi manusia merupakan hak dasar, pemberian tuhan yang dimilki manusia selama hidup dan sesudahnya, serta tidakdapat dicabut dengan semaunya tanpa ketentuan hukum yang ada, jelas dan benar.

Selanjutnya dipertegas oleh Muladi alasan perlunya negara memberikan perlindungan terhadap korban individu maupun perlindungan bagi masyarakat harus berdasarkan argumen kontrak sosial dan argumen solidaritas sosial. guna mencapai tujuan tersebut, maka pelaksanaan perlindungan tidak boleh dipisahkan dari prinsip dasar perlindungan anak dalam konvensi hak anak dan kebudayaan. ${ }^{8}$

Korban suatu tindak pidana (kejahatan) sering kali dibuat kecewa oleh praktik-praktik penyelenggaraan hukum yang lebih condong memperhatikan bahkan melindungi hak-hak asasi tersangka, sedangkan hak-hak asasi korban lebih banyak diabaikan. ${ }^{9}$

Perlu diperhatikan pula bahwa proses peradilan pidana, kedudukan korban sebagai pihak dalam perkara dibandinkan hanya sebagai saksi haruslah mendapat pengakuan yang wajar. $^{10}$ Dalam Teori hukum pidana, pengaturan mengenai pelayanan terhadap korban tindak pidana mendasarkan pada 2 model : ${ }^{11}$

a. Model hal procedural (the procedural Right Model) penekanan diberikan kepada korban untuk dimungkinkan si korban dapat memainkan peranan aktif dalam

8 Muchsin dan Koeswahyono Iman, Aspek Kebijaksaan Hukum Penatagunaan Tanah dan Penataan Ruang, Sinar Grafika, Jakarta, 2008, hlm. 31

9 Suparman Marzuki, Pelecehan Seksual, Fakultas Hukum UI, Yogyakarta, 1995, hlm. 197

10 Mardjono Reksodipur, Beberapa catatan umum tentang masalah korban dalam victimologi sebuah bunga rampai, Sinar Grafika, Jakarta, 1987, hlm. 105

${ }^{11}$ Dikdik M. Arif Mansyur dan Elissatris Gultom, Urgensi Korban kejahatan antara norma dan realita, RajaGrafindo, Jakarta, 2007, hlm. 85 


\section{Jurnal Tripantang}

Fakultas Hukum Universitas Tamansiswa Palembang

proses jalannya peradilan pidana. Dalam hal ini korban dapat memperjuangkan dan memperoleh apa-apa saja yang menjadi haknya.

b. Model pelayananan (The Services Model), Penekanan diletakkan pada perlunya diciptakan standar resmi bagi pembinaan korban tindak pidana yang dapat digunakan oleh Polisi dan aparat penegak hukum lainnya.

Perlindungan hukum terhadap anak merupakan upaya perlindungan berbagai kebebasan hak asasi anak (fundamental right and freedom of children) serta berbagai kepentingan yang berhubungan dengan kesejateraan anak. Perlindungan hukum bagi anak mencakup lingkup yang luas. Dalam perspektif kenegaraan, negara melindungi warga negaranya termasuk didalamnya terhadap anak dapat ditempatkan dalam pembukaan undang-undang Dasar 1945 yang tercermin pada alinea ke-IV, di dalam penjabaran BAB XA tentang Hak Asasi Manusia, khususnya untuk perlindungan terhadap anak.

UUD 1945 jelas menyatakan bahwa negara memberikan perlindungan kepada fakir miskin dan anak-anak terlantar. Masalah kemiskinan semakin menjadi penyakit yang terus menerus muncul dinegara ini, termasuk berbagai kejahatan yang terjadi menimpa anak-anak dinegara ini, termasuk bebagai kejahatan yang terjadi menimpa anak-anak di negara ini yang faktor utamanya disebabkan oleh kemiskinan. Faktor kemiskinan ini mempunyai kontribusi besar dalam tindakan penelantaran anak yang dilakukan oleh orang tua kandung. ${ }^{12}$ Kemudian juga perlindungan spesifik hak anak sebagian dari hak Asasi manusia, masud dalam Pasal 28 B ayat (2) bahwa setiap anak berhak atas kelangsungan hidup, tumbuh dan berkembang, serta memperoleh perlindungan darim kekerasan dan diskrimnasi.

Perlindungan Anak berdasarkan Pasal 1 ayat (2) Undang-undang Republik Indonesia Nomor 35 Tahun 2014 tentang perubahan atas undang-undang Nomor 23 Tahun 2002 tentang perlindungan anak menyatakan bahwa : Perlindimgan anak

12 Emelia Krisnawati, Aspek Hukum Perlindungan Anak, Bandung, CV. Utomo, hlm. 1 
adalah kegiatan untuk menjamin dan melindungi anak dan hak-haknya agar dapat hidup, tumbuh, kembang dan berpartisipasi, secara optimal sesuai harkat dan martabat perlindungan dari kekerasan dan diskriminasi. Anak sebagai korban kesusilaan tentunya mengalami penderitaan, baik secara maupun psikis. Negara sbagai penjamin kehidupan bermasyarakat bermasud memberikan perlindungan secara khusus kepada anak agar terhindar dari upaya ekspoitasi oleh pihak-pihak tertentu. Salah satu instrumen yang digunakan dalam perlundungan anak adalah hukum perlindungan hukum bagi anak dapat diartikan sebagai upaya yang berhubungan dengan kesejateraan anak. ${ }^{13}$

Selanjutnya kitapun dapat melihat perlindungan hak anak Indonesia dalam UU No.4 Tahun 1979 tentang kesejateraan anak yang bersamaan dengan penetapan tahun 1979 sebagai Tahun anak internasional selanjutnya Indonesia aktif terlibat dalam pembahsan konvensi hak anak tahun 1989 yang kemudian diratifikasi melalui Keppres 36 Tahun 1990. ${ }^{14}$

Perlindungan hukum korban kejahatan perlu memperoleh perhatian yang serius, masalah kejadian dan asasi dalam kaitan dengan penegakan hukum pidana memang bukan merupakan pekerjaan yang sederhana untuk direalisasikan. Banyak peristiwa dalam kehidupan dalam masyarakat yang menunjukan bahwa jelas dalam pancasila sebagai falsafah hidup bangsa Indonesia, masalah perikemanusiaan dan perikeadilan mendapat tempat sangat penting sebagai perwujud dari sila kemanusian yang adil dan beradap serta sila keadilan sosial bagi seluruh rakyat Indonesia.

${ }^{13}$ Harris Pratama Teguh, Teori dan Praktek Perlindungan Anak dalam Hukum Pidana, Andi Offset, Yogyakarta, 2018, hlm. 1

14 M. Nasir Djamil, Anak Bukan Untuk Dihukum, Sinar Grafika, Jakarta, 2013, hlm. 28 


\section{Jurnal Tripantang}

Fakultas Hukum Universitas Tamansiswa Palembang

Mengabaikan perlindungang anak adalah suatu yang tidak dapat dipertanggungjawabkan, kurang perhatian, dan tidak diselenggarakannya perlindungan anak akan membawa akibat yang sangat merugikan diri sendiri dikemudian hari. Sebagai contoh kurang perhatiannya masalah penegakan hukum pidana dimana masalah ini berkaitan dengan perlindungan hukum terhadap korban tindak pidana, dan dalam penyelesaian perkara pidana banyak ditentukan korban kejahatan kurang memperoleh hukum yang memadai, baik perlindungan yang sifatnya immaterial maupun material. ${ }^{15}$

Setiap anak selama dalam pengasuhan orang tuanya orang tuanya yang bertanggungjawab atas pengasuhan sudah selayaknya mendapatkan perlindungan dan perlakuan yang salah menurut peraturan yang berlaku di Indonesia saat ini. Masalah perlindungan hukum bagi anak-anak merupakan salah satu sisi pendekatan untuk melindungi anak-anak, oleh sebab itu masalahnya tidak semata-mata bisa didekati secara yuridis, tetapi perlu pendekatan yang lebih luas yaitu ekonomi, sosial, dan budaya. ${ }^{16}$

Pemberian perlindungan kepada anak sebagai korban didasarkan pada undang-undang Republik Indonesia Nomor 35 Tahun 2014 tentang perubahan atas Undang-undang Nomor 23 Tahun 2002 tentang perlindungan anak. Dalam Undang tersebut disebutkan bahwa hak-hak anak antara lain : Pasal 4, Pasal 5, Pasal 6, Pasal 7, Pasal 8, Pasal 9, Pasal 10, Pasal 11, Pasal 12, Pasal 13, Pasal 14, Pasal 15, Pasal 16, Pasal 17, Pasal 18.

Perlindungan khusus bagi anak yang menjadi korban tindak pidana sebagai mana diatur dalam Pasal 64 ayat (3) Undang-undang Republik Indonesia Nomor 35

15 Didik Arif Mansur, Urgensi Perlindungan korban kejahatan, Raja Grafindo persada, Jakarta, hlm 11-12

${ }^{16}$ Abdul Haris G. Nusantara, Politik hukum Indonesia, Yayasan Lembaga Bantuan Hukum Indonesia, Jakarta, 1988, hlm.19 
tahun 2014 tentang perubahan atas undang-undang Nomor 23 tahun 2002 tentang perlindungan anak, dilaksanakan melalui :

1. Upaya rehabilitasi baik dalam lembaga maupun diluar lembaga.

2. Upaya perlindungan dari penderitaan indentitas melalui media massa dan untuk menghidari labelisasi.

3. Pemberian keselamatan bagi saksi korban dan saksi ahli, baik fisik, mental maupun sosial.

4. Pemberian aksesibilitas untuk mendapatkan informasi mengenai perkembangan perkara.

Menurut Pasal 1 Undang-undang Republik Indonesia Nomor 13 tahun 2006 tentang perlindungan saksi dan korban yang dimaksud korban adalah seseorang yang mengalami penderitaan fisik, mental, dan atau kerugian ekonomi yang diakibatkan suatu tindak pidana. Pelayanan terhadap korban tindak pidana adalah suatu usaha pelayanan mental, fisik, sosial, ekonomi terhadap mereka yang telah menjadi korban dan mengalami penderitaan akibat tindakan seseorang yang diangggap sebagai suatu tindak pidana.

Dalam hal korban membawa permasalahannya kepengadilan, maka harus tersedia kemukianan untuk mendapatkan bantuan hukum secara Cuma-Cuma untuk mereka yang tidak mampu. Sementara itu untuk para korban yang mengalami penderitaan fisik harus pula tersedia fasilitas menampung pengobatan mereka. Khusus untuk mereka yang mengalami tekanan batin korban pemerkosaan dan penganiayaan seharusnya dapat disediakan pula fasilitas khusus dengan pengaganan para ahli.

Hukum memilki otoritas tertinggi untuk menentukan kepentinggan manusia yang perlu dilindungi dan diatur. Jadi hukum tidak hanya melindungi hak 
dan kepentingan, melainkan juga kehendak. Jadi bukan hanya kepentingan orang itu yang dilindungi oleh hukum, melainkan juga kehendak orang tersebut. ${ }^{17}$

Menurut Philipus M. Hadjon, perlindungan hukum adalah suatu kondisi subjektif yang menyatakan hadirnya keharusan pada diri sejumlah subjek hukum untuk segera memperoleh sumber daya, guna kelansungan eksistensi subjek hukum yang dijamin dan dilindungi oleh hukum, agar kekuatannya secara terorganisir dalam proses pengambilan keputusan politik maupun ekonomi, khususnya pada distribusi sumber daya baik pada pringkat indivindu maupun structural. ${ }^{18}$ Dengan menitik beratkan pada tindakan pemerintahan (bestuurshandeling) membedakan perlindungan hukum bagi rakyat dalam dua macam yaitu:

1. Perlindungan hukum preventif bertujuan mencegah terjadinya sengketa, yang member kesempatan pada rakyat untuk mengajukan keberatan (inspraak) atau pendapatnya sebelum keputusan pemerintah mendapat bentuk yang definitif, yang sangat besar artinya bagi tindakan pemerintah yang didasarkan kepada kebebasan bertindak karena pemerintah terdorong untuk bersikap hati-hati dalam pengambil keputusan berdasarkan diskresi.

2. Perlindungan hukum represif, bertujuan untuk menyelesaikan terjadinya sengketa, termasuk penanganan perlindungan hukum bagi rakyat oleh peradilan umum dan peradilan administrasi di Indonesia.

Pelindungan hukum represif berfungsi untuk menyelesaikan sengketa yang muncul apabila terjadi suatu pelanggaran. Dewasa ini di Indonesia terdapat berbagai badan yang menangani perlindungan bagi rakyak. Menurut Rochmat Soemitro dapat dikelompokkan menjadi tiga bagian yaitu :

b. Peradilan dalam lingkup peradilan umum.

17 Satjipto Rahardjo, Ilmu Hukum, Citra Adibakti, Bandung, 2000, hlm. 69

18 Tini Rusmini Gorda, Hukum Perlindungan Anak Korban Pedopelia, Setara Press, Malang, 2017, hlm. 79 


\section{Jurnal Tripantang}

Fakultas Hukum Universitas Tamansiswa Palembang

c. Intansi pemerintah yang merupakan lembaga banding administrasi.

d. Badan badan Khusus

Bentuk perlindungan hukum terjhadap anak dibawah umur yang menjadi korban tindak pidana persetubuhan adalah perlindungan preventif, sesuai dengan Undang-undang Nomor 35 Tahun 2014 atas perubahan Nomor 23 Tahun 2002 tentang Pelindungan anak.

Sedangkan menurut Undang-Undang Nomor 35 Tahun 2014 tentang Perubahan Atas Undang-Undang No. 23 Tahun 2002 tentang Perlindungan Anak, dijelaskan dalam pasal 78, pasal 82, dan pasal 88, bahwa ketentuan pidana dan jenis pidana yang diberikan kepada pihak pelaku tindak pidana persetubuhan terhadap anak disebutkan secara jelas yaitu sanksi yang diberikan berupa sanksi pidana penjara dan denda.

Di dalam Pasal 81 ayat (1) menyebut setiap orang yang dengan sengaja melakukan kekerasan atau ancaman kekerasan memaksa anak melakukan persetubuhan dengannnya atau dengan orang lain, dipidana dengan pindana penjara paling lama 15 (lima belas) tahun dan paling singkat 5 (lima) tahun dan denda paling banyak Rp5.000.000.000,00 (lima milyar rupiah).

Sementara, Pasal 82 UU Undang-Undang Nomor 35 Tahun 2014 tentang Perubahan Atas Undang-Undang No. 23 Tahun 2002 berbunyi setiap orang yang dengan sengaja melakukan kekerasan atau ancaman kekerasan, memaksa, melakukan tipu muslihat, serangkaian kebohongan, atau membujuk anak untuk melakukan atau membiarkan dilakukan perbuatan cabul, dipidana dengan pidana penjara paling lama 15 (lima belas) tahun dan paling singkat 5 (lima) tahun dan denda paling banyak Rp 5.000.000.000,00 (lima milyar rupiah).

Mengacu pada perubahan ancaman hukuman terutama Pasal 81 ayat (1) dan Pasal 82 pada Undang-Undang Perlindungan Anak, ancaman terhadap tindak kejahatan kekerasan seksual yang sebelumnya paling singkat 3 (tiga) tahun menjadi 5 (lima) tahun dan paling lama 15 (lima belas) tahun dan denda paling 
banyak Rp 5.000.000.000,00 (lima milyar rupiah) sebelumnya Rp. 60.000.000,(enam puluh juta) rupiah, menunjukkan bahwa menaikkan ancaman hukuman bermaksud untuk memberikan efek jera pada pelaku dan bagi pelaku terbukti bersalah untuk tidak mengulangi perbuatan tersebut.

Namun, pada senyatanya pasal-pasal pengancam itu agaknya tidak membuat takut atau jera pelaku kekerasan seksual, terbukti dengan kemunculan kasus-kasus kekerasan seksual di sejumlah daerah di Tanah Air. Berdasarkan data SIMFONI Kementerian Pemberdayaan Perempuan dan Perlindungan Anak (PPA) dari tanggal 1 Januari - 19 Juni 2020 telah terjadi 3.087 kasus kekerasan terhadap anak, diantaranya 852 kekerasan fisik, 768 kekerasan fisik dan 1.848 kasus kekerasan seksual. ${ }^{19}$ Kekerasan seksual terhadap anak dapat dilakukan oleh orang dewasa juga pelakunya adalah anak. Berdasarkan data pada Satuan Reserse dan Kriminal (Satreskrim) Kepolisian Resor Kota Besar (Polrestabes) Palembang jumlah tindak pidana kekerasan seksual pelakunya Anak terhadap anak adalah sebagai berikut:

\section{Tabel 1}

Jumlah Tindak Pidana Kekerasan Penganiayaan, Persetubuhan dan Pencabulan Yang dilakukan Anak dengan Korban Anak Tahun 2019 - 2021 di Polrestabes Palembang

\begin{tabular}{|l|l|c|c|c|}
\hline No & Jenis Tindak Pidana & $\begin{array}{l}\text { Jumlah } \\
\text { Tahun 2019 }\end{array}$ & $\begin{array}{l}\text { Jumlah } \\
\text { Tahun 2020 }\end{array}$ & $\begin{array}{l}\text { Jumlah } \\
\text { Tahun 2021* }\end{array}$ \\
\hline 1 & $\begin{array}{l}\text { Penganiayaan } \\
\text { Pasal 80 UU RI No. 23 Tahun 2002 }\end{array}$ & 40 & 13 & 1 \\
\hline 2 & $\begin{array}{l}\text { Persetubuhan } \\
\text { Pasal 81 UU RI No. 23 Tahun 2002 }\end{array}$ & 19 & 10 & - \\
\hline 3 & $\begin{array}{l}\text { Pencabulan } \\
\text { Pasal 82 UU RI No. 23 Tahun 2002 }\end{array}$ & 3 & 5 & 1 \\
\hline & Jumlah & 62 & 28 & 2 \\
\hline
\end{tabular}

* Data hingga Maret 2021

Sumber: Unit PPA Polrestabes Palembang

19 Kementerian Pembardayaan Perempuan dan Perlindungan Anak Republik Indonesia, Angka Kekerasan Terhadap Anak Tinggi di masa Pandemi, Kemen PPA Sosialisasikan Protokol Perlindungan Anak,www. Kemenppa.go.id. diakses 8 Aril 2021 


\section{Jurnal Tripantang}

Fakultas Hukum Universitas Tamansiswa Palembang

Terhadap jenis tindak pidana tersebut diatas dengan ancaman pidana diatas 7 (tujuh) tahun maka tidak dapat dilakukan diversi ${ }^{20}$, sebagaimana ketentuan pada Pasal 7 UU No. 11 Tahun 2012 tetnang Sistem Peradilan Pidana Anak bahwa diversi hanya dapat dilakukan terhadap tindak pidana dengan ancaman pidana penjara dibawah 7 (tujuh) tahun dan bukan pengulangan.

Data tersebut diatas menunjukkan adanya kecenderungan penurunan tindak pidana kekerasan terhadap anak yang dilakukan oleh Anak meskipun untuk tahun 2021 data masih sampai akhir bulan maret. Meskipun demikian yang harus diperhatikan bahwa data kekerasan terhadap anak termasuk kekerasan seksual tidaklah selalu menunjukkan data yang sebenarnya, sebab senyatanya masih banyak kasus yang terjadi tidak dilaporkan oleh sebagian masyarakat ke aparat penegak hukum untuk ditindaklanjuti ke proses peradilan pidana. ${ }^{21}$

Aspek perlindungan terhadap anak korban tindak pidana persetubuhan merupakan usaha atau kegiatan bersama yang bertujuan untuk mengusahakan pemenuhan hak anak dalam menjamin kemerdekaan hak asasinya. Usaha perlindungan anak akibat kekerasan seksual menekankan pamahaman terhadap penegakan peraturan yang sudah ada dengan melibatkan unsur kepentingan bersama dan usaha bersama. Menurut kementerian PPA RI bahwa makin meningkatnya kekerasan terhadap anak menunjukkan bahwa masih banyak pihak yang belum paham akan pentingnya pengasuhan anak memberikan kasih sayang, dan yang sangat penting apabila semua pihak dapat memperhatikan kebutuhan dasar anak agar mereka tidak terjerumus dalam tindak pidana (kejahatan), sehingga anak merasa diterima dan dapat berbaur dengan masyarakat. ${ }^{22}$ Oleh karena itu, masalah perlindungan anak termasuk korban tindak pidana persetubuhan

${ }^{20}$ Diversi adalah Pengalihan penyelesaian perkara Anak dari proses peradilan pidana ke proses di luar peradilan pidana.

${ }^{21}$ Marihot D. Saing dan Mujiburrahman, Aspek-Aspek Hukum Sistem Peradilan Pidana Anak di Indonesia, Noer Fikri, 2019, hlm. 5

${ }^{22}$ Kementerian Pembardayaan Perempuan dan Perlindungan Anak Republik Indonesia, op.cit 


\section{Jurnal Tripantang}

Fakultas Hukum Universitas Tamansiswa Palembang

mencakup aspek perlindungan hak asasi anak dan kebebasan anak pada tahap perkembangannya.

Undang-Undang Undang-Undang Nomor 35 Tahun 2014 tentang Perubahan Atas Undang-Undang No. 23 Tahun 2002 tentang Perlindungan Anak keberadaannya merupakan alat hukum yang mampu untuk melindungi anak dalam berbagai tindak pidana khususnya kekerasan seksual terhadap anak. UndangUndang tersebut menyatakan bahwa kekerasan seksual terhadap anak merupakan tindak pidana sehingga pelaku dapat diajukan ke kepolisian atas pendampingan pihak terkait. Di Unit Perlindungan Perempuan dan Anak (PPA) Satuan Reserse dan Kriminal (Satreskrim) Kepolisian Resor Kota Besar (Polrestabes) Palembang diperoleh hasil bahwa penerapan dan implementasi perlindungan terhadap korban tindak pidana persetubuhan terhadap anak di bawah umur mendasarkan pada Pasal 82 Undang-Undang Perlindungan Anak terhadap pelaku yang dengan sengaja melakukan kekerasan maupun dengan ancaman kekerasan, memaksa, tipu muslihat, melakukan serangkaian kebohongan atau membujuk anak di bawah umur untuk melakukan atau membiarkan dilakukan perbuatan cabul.

Ketentuan Pasal 3 Undang-Undang Nomor 35 Tahun 2014 tentang Perubahan Atas Undang-Undang No. 23 Tahun 2002 tentang Perlindungan anak menegaskan ruang lingkup perlindungan anak meliputi semua kegiatan untuk menjamin hak-hak anak agar dapat hidup, tumbuh, berkembang dan berpartisipasi secara optimal sesuai dengan harkat dan martabat kemanusiaan, serta mendapat perlindungan dari kekerasan dan diskriminasi.

Maksud perlindungan kekerasan terhadap anak di atas terhadap kasus kekerasan seksual anak diperjelas dalam Pasal 69 ayat 1 Undang-Undang Nomor 35 Tahun 2014 tentang Perubahan Atas Undang-Undang No. 23 Tahun 2002 yang meliputi kekerasan fisik, psikologis dan kekerasan selain melalui cara preventif dengan sosialisasi peraturan perundang-undangan juga aktif untuk melakukan pemantauan, pelaporan dan secara represif dengan penjatuhan sanksi melalui 


\section{Jurnal Tripantang}

Fakultas Hukum Universitas Tamansiswa Palembang

proses peradilan pidana. Sedangkan upaya yang dilakukan terhadap Anak korban kejahatan seksual diatur dalam Pasal 69A meliputi kegiatan selain edukasi tentang kesehatan reproduksi juga nilai agama, dan nilai kesusilaan, mengembalikan ke masyarakat melalui rehabilitasi sosial, pendampingan secara psikososial serta dalam hal adanya proses perdilan pidana dengan memberikan pendampingan pada setiap pemeriksaan muai dari penyidikan, penuntutuan sampai pemeriksaan di pengadilan.

Implementasi perlindungan terhadap anak korban kekerasan seksual dalam pasal-pasal undang-undang tentang Perlindungan Anak tersebut yaitu : Pertama, Pasal 66 yang menyatakan perlindungan terhadap anak dalam situasi tereksploitasi secara ekonomi dan/atau seksual maupun anak yang diperdagangkan menjadi tanggung jawab pemerintah, Pemerintah Daerah dan lembaga negara lain. Kedua, Pasal 82 yang menyatakan bahwa setiap orang yang dengan sengaja melakukan kekerasan maupun dengan ancaman kekerasan, memaksa dengan tipu muslihat dan serangkaian kebohongan serta membujuk anak untuk melakukan perbuatan cabul dipidana dengan pendekatan penerapan sanksi pidana paling lama 15 (lima belas) tahun dan paling singkat 5 (lima) tahun pidana penjara dan denda paling banyak Rp. 5.000.000.000,- (lima miliar rupiah).

Tindakan persetubuhan terhadap anak dibawah umur sebenarnya merupakan tindakan yang bukan hanya secara fisik, tetapi juga psikologis, sosial. Dampak yang dirasakan bagi si anak bukan hanya secara fisik saja, tetapi juga psikologisnya serta sosialnya. Hal ini akan memberikan dampak traumatik yang mendalam bagi si anak, bahkan anak korban kekerasan seksual kerap menutup diri dari lingkungan tempat tinggal karena beban yang dialami serta dampak-dampak lain akibat kekerasan seksual yang dialami oleh korban.

Masalah perlindungan anak korban kekerasan seksual pada dasarnya adalah sama dengan penegakan hukum secara keseluruhan. Oleh karena itu implementasi penegakan hukum dipengaruhi oleh beberapa hal seperti peraturan hukum, aparat 


\section{Jurnal Tripantang}

Fakultas Hukum Universitas Tamansiswa Palembang

penegak hukum, budaya hukum masyarakat (tingkat kesadaran hukum) dan budaya yang ada di masyarakat itu sendiri.

Langkah-langkah dalam mencermati isu kasus kekerasan seksual terhadap anak setidaknya memerlukan penyelenggaraan nyata untuk mengatasi dan mencegah perilaku menyimpang dari masyarakat. Diantaranya perlu di galakkan program aksi perlindungan terhadap anak, baik oleh pemerintah, aparat penegak hukum dan masyarakat luas secara keseluruhan.

Upaya hukum ditingkatkan dengan memberikan sanksi kepada para pelaku tindak kekerasan terhadap anak di bawah umur serta adanya pemantauan dan monitoring dari lembaga yang ditunjuk oleh pemerintah.Tindak kekerasan pada anak merupakan tindakan yang menimbulkan rasa sakit secara fisik dan psikologis serta membuat anak merasa tidak nyaman (trauma berlebihan). Besar kecilnya luka yang dialami anak tergantung pada kapasitas tindak kekerasan pelaku terhadap karakteristik anak di bawah umur.

\section{PENUTUP}

Ditinjau dari Undang-Undang Nomor 35 Tahun 2014 tentang Perubahan Atas UndangUndang No. 23 Tahun 2002 tentang Perlindungan anak baik secara eksplisit maupun implisit diatur pada Pasal 4 samapi Pasal 18 sebagai semua kegiatan untuk menjamin hak-hak anak agar dapat hidup, tumbuh, berkembang dan berpartisipasi secara optimal sesuai dengan harkat dan martabat kemanusiaan, serta mendapat perlindungan dari kekerasan dan diskriminasi. Secara khusus tentang perlindungan kekerasan terhadap korban Anak dalam kasus kekerasan seksual anak diatur dalam Pasal 69 dan 69A bahwa korban Anak atas kekerasan fisik, psikologis dan kekerasan seksual berhak mendapat perlindungan dari Pemerintah, Pemerintah Daerah dan lembaga negara lainnya baik untuk pemulihan secara psikis dan fisik, rehabiliasi sosial, pendampingan dalam proses peradilan pidana. 


\section{DAFTAR PUSTAKA}

Satjipto Rahardjo, Ilmu Hukum, Citra Adibakti, Bandung, 2000, hlm. 69

Tini Rusmini Gorda, Hukum Perlindungan Anak Korban Pedopelia, Setara Press, Malang, 2017, hlm. 79

H.R. Abdussalam\& Adri Desasfuryanto, Hukum Perlindungan Anak, PTIK, Jakarta, 2014, hlm. 1

Nashriana, Perlindungan Hukum Pidana Bagi Anak Di Indonesia, Rajawali Press, Jakarta, 2011, hlm. 2

Satjipto Rahardjo, Biarkan Hukum Mengalir, Catatan Kritis Tentang Pergulatan manusia dan hukum, Kompas, Jakarta, 2008, hlm. 8

Darwin Prints, Hukum Anak Indonesia, (Citra Bakti, Bandung, 2002, hlm. 2

https://ww.kompas.com tag diakses tanggal 14-4-2021 jam 14.00 Wib

Titon Slamet Kurnia, Reparasi terhadap korban Pelanggaran HAM di Indonesia, Bandung, 2005, Aditya Bakti, hlm. 6-7

Suparman Marzuki, Pelecehan Seksual, Fakultas Hukum UI, Yogyakarta, 1995, hlm. 197

Mardjono Reksodipur, Beberapa catatan umum tentang masalah korban dalam victimologi sebuah bunga rampai, Sinar Grafika, Jakarta, 1987, hlm. 105

Dikdik M. Arif Mansyur dan Elissatris Gultom, Urgensi Korban kejahatan antara norma dan realita, RajaGrafindo, Jakarta, 2007, hlm. 85

Emelia Krisnawati, Aspek Hukum Perlindungan Anak, Bandung, CV. Utomo, hlm. 1

Harris Pratama Teguh, Teori dan Praktek Perlindungan Anak dalam Hukum Pidana, Andi Offset , Yogyakarta, 2018, hlm. 1

Muchsin dan Koeswahyono Iman, Aspek Kebijaksaan Hukum Penatagunaan Tanah dan Penataan Ruang, Sinar Grafika, Jakarta, 2008, hlm. 31

M. Nasir Djamil, Anak Bukan Untuk Dihukum, Sinar Grafika, Jakarta, 2013, hlm. 28

Didik Arif Mansur, Urgensi Perlindungan Korban Kejahatan, Raja Grafindo persada, Jakarta, hlm 11-12

Abdul Haris G. Nusantara, Politik Hukum Indonesia, Yayasan Lembaga Bantuan Hukum Indonesia, Jakarta, 1988, hlm.19 